\title{
Cross mapping of nursing diagnoses in infant health using the International Classification of Nursing Practice*
}

\author{
MAPEAMENTO CRUZADO DE DIAGNÓSTICOS DE ENFERMAGEM EM PUERICULTURA \\ UTILIZANDO A CLASSIFICAÇÃO INTERNACIONAL DE PRÁTICAS DE ENFERMAGEM
}

\section{MAPEO CRUZADO DE DIAGNÓSTICOS DE ENFERMERÍA EN PUERICULTURA UTILIZANDO LA CLASIFICACIÓN INTERNACIONAL DE LAS PRÁCTICAS DE ENFERMERÍA}

\section{Thaís Savini Luciano ${ }^{1}$, Maria Miriam Lima da Nóbrega ${ }^{2}$, Eliana Campos Leite Saparolli³, Alba Lucia Bottura Leite de Barros ${ }^{4}$}

\begin{abstract}
This was a descriptive, retrospective stu$d y$, with a quantitative method, with the aim of analyzing the nursing diagnoses contained in the records of children of 0 to 36 months of age who attended infant health nursing consults. A documentary analysis and the cross-mapping technique were used. One hundred eighty-eight different nursing diagnoses were encountered, of which 33 (58.9\%) corresponded to diagnoses contained in the Nomenclature of Nursing Diagnoses and Interventions and $23(41.1 \%)$ were derived from ICNP ${ }^{\circledR}$ Version 1.0. Of the 56 nursing diagnoses, $43(76.8 \%)$ were considered to be deviations from normalcy. It was concluded that the infant health nursing consults enabled the identification of situations of normalcy and abnormality, with an emphasis on the diagnoses of deviations from normalcy. Standardized language favors nursing documentation, contributing to the care of the patient and facilitating communication between nurses and other health professionals.
\end{abstract}

\section{DESCRIPTORS}

Nursing diagnosis

Child

Classification

Child health

Primary Health Care

\section{RESUMO}

Estudo descritivo e retrospectivo, com abordagem quantitativa, que objetivou analisar os diagnósticos de enfermagem constantes de prontuários de crianças de 0 a 36 meses de idade atendidas em consulta de enfermagem em puericultura. Utilizouse a análise documental e a técnica de mapeamento cruzado. Foram encontrados 188 diferentes diagnósticos de enfermagem, dos quais 33 (58,9\%) correspondiam a diagnósticos contidos na Nomenclatura de Diagnósticos e Intervenções de Enfermagem e $23(41,1 \%)$ eram provenientes da CIPE $^{\circledR}$ Versão 1.0. Dos 56 diagnósticos de enfermagem, $43(76,8 \%)$ foram considerados de desvio de normalidade. Conclui-se que as consultas de enfermagem à criança permitem identificar situações de normalidade e anormalidade, com destaque para os diagnósticos de desvio de normalidade. A padronização da linguagem favorece a documentação de enfermagem, contribuindo para o cuidado ao paciente e facilitando a comunicação entre os enfermeiros e outros profissionais de saúde.

\section{DESCRITORES \\ Diagnóstico de enfermagem \\ Criança \\ Classificação \\ Saúde da criança \\ Atenção Primária à Saúde}

\begin{abstract}
RESUMEN
Estudio descriptivo y retrospectivo de abordaje cuantitativo, cuyo objetivo fue analizar los diagnósticos de enfermería (DE) formulados en los registros de niños de 0 a 36 meses de edad atendidos en la consulta de enfermería en Puericultura. Se utilizó el análisis documental y la técnica de mapeo cruzado, encontrándose 188 diferentes diagnósticos de enfermería, de los cuales 33 (58,6\%) correspondían a diagnósticos contenidos en la Nomenclatura de Diagnósticos e Intervenciones en Enfermería adoptada en la red básica de Curitiba, y $23(41,1 \%)$ eran provenientes de la $\mathrm{CIPE}^{\circledR}$ Versión 1.0. De los 56 $\mathrm{DE}$, se encontraron $43(76,8 \%)$ diagnósticos de desviación de la normalidad. Se concluyó que las consultas de enfermería infantil permiten identificar situaciones de normalidad y anormalidad, destacándose los diagnósticos de desviación de la normalidad y que la estandarización del lenguaje de enfermería favorece la documentación de enfermería, contribuyendo con el cuidado del paciente y facilitando la comunicación entre los enfermeros y otros profesionales de la salud.
\end{abstract}

\author{
DESCRIPTORES \\ Diagnóstico de enfermería \\ Niño \\ Clasificación \\ Salud del niño \\ Atención Primaria de Salud
}

\footnotetext{
* Extracted from the course conclusion work, "Adequacy of the nursing diagnosis taxonomies in infant health nursing consultations", Undergraduate degree in nursing, Paulista School of Nursing, Universidade Federal de São Paulo (Federal University of São Paulo), 2009. ${ }^{1}$ Nurse in the intensive care unit of the Hospital São Luiz Morumbi, São Paulo, SP, Brasil.thais_savini@hotmail.com ${ }^{2}$ Associate Professor, Department of Nursing in Public Health and Psychiatry, Universidade Federal da Paraíba (Federal University of Paraíba, João Pessoa, PB, Brasil. ${ }^{3}$ Adjunct Professor, Department of Administration and Public Health, Paulista School of Nursing, Universidade Federal de São Paulo (Federal University of São Paulo), São Paulo, SP, Brasil. ${ }^{4}$ Professor, Department of Medical-Surgical Nursing, Paulista School of Nursing, Universidade Federal de São Paulo (Federal University of São Paulo),
} São Paulo, SP, Brasil. 


\section{INTRODUCTION}

The infant health nursing consult is a strategy of care directed toward monitoring the growth and development of the infant, with a view toward promotion, protection and health recuperation of the child. This care practice is a private activity of the nurse, supported by the legislation, Professional Practice of Nursing (Law 7.498/86), and assured by COFEN (Resolution 358/2009)(1). The resolution, conducted in a systematic and continuous manner, allows the diagnosis of health needs, nursing prescription and the provision of outcomes and qualified care ${ }^{(1)}$.

The nursing consultation is usually inserted within the local programming and should be combined with other activities, of an individual or collective character, to ensure the completeness and resolvability of the care ${ }^{(2)}$.

In the Resolution of COFEN already cited, the nursing process in extra-hospital care corresponds to the usually named nursing consult, and is organized in five interrelated, interdependent and recurring steps, namely: data collection or nursing history, nursing diagnosis, planning, implementation and evaluation ${ }^{(1)}$. This systematized process of nursing care provides conditions to individualize and administer nursing care, enabling greater integration of the nurse with the user, the family and community ${ }^{(3-4)}$.

The COFEN resolution no. 358/09 considers that the operationalization and documentation of the nursing process provides evidence of the contribution of nursing in the care of the population, increasing professional visibility and recognition.

The nursing diagnosis step can be understood as a process of clinical judgment, therefore, in the traditional practice of nursing, or as a term that expresses the conclusion of the clinical judgment that is focused on responses presented by the clients. What takes on a certain novelty are the initiatives to construct a language system shared by nurses ${ }^{(5-6)}$. The literature shows that the lack of a universal language, which establishes the definition and description of professional practice, has compromised the development of nursing as a science ${ }^{(7)}$.

Various specialists affirm that standardization of language provides diverse benefits for the profession, among these: providing a uniform language for communication between nurses and other health professionals; enabling documentation of nursing information, contributing to the care of the patient; and allowing the development of electronic nursing information systems ${ }^{(8)}$.

Nursing has sought uniformity of its language through various initiatives for the development of classifications for its professional practice. One of these classifications, which was used as reference in this study, is the International Classification for Nursing Practice $\left(\right.$ ICNP $\left.^{\circledR}\right)$, organized by the International Council of Nurses (ICN), and defined as a classification of phenomena (or diagnoses), actions (or interventions), and nursing outcomes.

THE ICNP ${ }^{\circledR}$ is a dynamic and changeable instrument, and is in constant evaluation. The first version was the Alpha (1996), which was subsequently reviewed during the preparation of the Beta Version (1999) and the Beta 2 Version (2001), which, in turn, was reformulated, and the ICNP ${ }^{\circledR}$ Version 1.0 was developed, in 2005, and the ICNP ${ }^{\circledR}$ Version 2.0 in 2009, which was translated and published in Brazil in 2011. On the ICN website, version 2013 is available. It is presented as a unifying framework for all systems of classification of elements of nursing practice available worldwide, which facilitates cross-mapping among local terms and classifications and existing vocabulary, sufficiently broad, and sensitive to cultural diversity ${ }^{(9)}$.

Revisions and innovations incorporated into ICNP ${ }^{\circledR}$ are a process in construction, with a view to reducing the ambiguity and redundancy in the language of nursing ${ }^{(10)}$. In this process of construction of the ICNP ${ }^{\circledR}$, it was noticed that while some existing classification systems already incorporate terms related to these fields of practice, there was still a need to identify and include new terms associated with primary health care (PHC) and the practice of nursing in community health services ${ }^{(11-12)}$.

Beginning with this consideration, the International Classification of Nursing Practice Project was designed and implemented in Brazil in public health (CIPESC), which produced a vocabulary inventory of community health nursing, starting from the identification of terms related to nursing phenomena and actions. At the end of the study, 99 terms and their respective definitions were validated by a panel of judges and suggested to the ICN to be added on the practice focus axis of the ICNP ${ }^{\circledR(11)}$.

The utilization of the different classification systems within Brazil is still embryonic, restricted to research, especially in graduate school, and some deployment attempts in education and health care practice ${ }^{(7)}$. Despite its benefits, the standardized nursing terminologies in the Brazilian daily practice are still underused ${ }^{(7)}$. What is observed many times is that the records are completed, but without the adoption of a uniform system, which is based on a classification ${ }^{(8)}$.

Among the experiences that have been developed in Brazil using the ICNP ${ }^{\circledR}$, the incorporation of the ICNP ${ }^{\circledR}$ Beta 2 version, of 2002, and the outcomes of CIPESC in the computerized medical record that is used throughout the basic network of the Municipal Health Secretariat of Curitiba-Paraná deserves to be highlighted. The nurses from Curitiba, to construct the nursing diagnoses and prescriptions in the areas of child health and women's health, developed the nomenclature of nursing diagnoses and interventions of the Basic Health Network of the
Cross mapping of nursing diagnoses in infant health using the International Classification of Nursing Practice Luciano TS, Nóbrega MML, Saparolli ECL, Barros ALBL 
Municipality of Curitiba ${ }^{(13)}$. This experience proved that it was possible to use the ICNP $^{\circledR}$ language in the APS, as an instrument for systematizing nursing practice in public health and, consequently, to increase the professional visibility and recognition of the nurse $\mathrm{e}^{(7)}$.

In this study, the Nomenclature of Nursing Diagnoses and Interventions of the Basic Health Network of the Municipality of Curitiba and the ICNP ${ }^{\circledR}$ Version $1.0^{(14)}$, of 2005 , were defined as the reference systems of classification $^{(13)}$. The reasons for this choice were due to the fact of the ICNP ${ }^{\circledR}$ and the outcomes of CIPESC containing terms frequently used in practice by nurses to name the situations encountered in their clinical work, whether they are deviations from normalcy or even its inexistence. It was also due to the fact that infant health nursing consultation performed in the outpatient clinic of the Cruz de Malta Care Center (CACM), where the research was conducted, were characterized as systematic nursing care within the primary care environment.

Given the situation presented, the question was: - Do the diagnostic terms found in the infant health nursing consultation, provided to children aged 0 to 36 months in the CACM, have similarities with the diagnoses of the Nomenclature of Nursing Diagnoses and Interventions of the Basic Health Network in Curitiba, and with the ICNP ${ }^{\circledR}$ version 1.0 ?

The study had as its overall objective to analyze the nursing diagnoses listed in the medical records of children 0 to 36 months of age treated in infant health nursing consultations at an outpatient clinic. Its specific objectives were: to identify the most frequent diagnoses established by the nurses and to compare these most frequent diagnoses with the Nomenclature of Nursing Diagnoses and Interventions of the Basic Health Network of Curitiba and the ICNP ${ }^{\circledR}$ Version 1.0.

\section{METHOD}

The population of this study consisted of the 400 records of the children in the age range of 0 to 36 months of age, attended in nursing consults during the year of 2008. For the definition of the sample, the value of $20 \%$ of the total of the medical records of children attending the nursing consultation during the period from June to December of 2008 was established, resulting in a total of 80 records, with analysis of one consult of each record selected.

The technique used for data collection was document analysis in order to verify the registration of diagnoses described in the care practice. These records were analyzed by means of cross-mapping, which is a method used to analyze data contained in the nursing process through the comparison between the existing information in the records of the patients and the reference classifications for nursing practice ${ }^{(8)}$.
In its utilization, four major steps were followed: 1) randomly recover $20 \%$ of the records of the patients seen in six months (June to December of 2008) in the CACM; 2) list all nursing diagnoses identified in those records; 3) group together all nursing diagnoses with similar concepts; and 4) cross map the similar nursing diagnoses to the diagnoses contained in the Nomenclature of Nursing Diagnoses and Interventions of the Basic Health Network of the Municipality of Curitiba and the ICNP ${ }^{\circledR}$ Version 1.0.

In addition to these four steps, the process of crossmapping implies the establishment of rules that can be determined to measure what was being delineated ${ }^{(8)}$. The six rules for cross-mapping in this research were: 1) selecting a diagnosis of the Nomenclature of Curitiba, based on similarity and on the same conceptualization of nursing diagnoses recorded in medical records; 2) determine a term (word used in the construction of a diagnosis) contained in the prescribed nursing diagnosis, which would assist in the identification of the most appropriate nursing diagnosis in said nomenclature; 3 ) to preferentially use the diagnosis (constructed by terms of the focus and judgment axes) employed in the nursing diagnosis prescribed, to select the correspondent diagnosis in the Nomenclature of Curitiba that used the ICNP ${ }^{\circledR}$ Beta 2 version; 4) to map the nursing diagnoses that used two concepts that suggested two diagnoses, when the actions were different; 5) to utilize the ICNP ${ }^{\circledR}$ version 1.0 in the case of the inability to perform the cross-mapping with the nomenclature, and choose the focus practice term of the ICNP ${ }^{\circledR} 1.0$ that had conceptual similarity with the recorded diagnosis in the medical record and, then, to combine the terms of the focus of practice and judgment axes for the description of the nursing diagnosis; and, 6) to identify the nursing diagnoses prescribed that, for whatever reason, could not be mapped.

The study was submitted for review and approval by the Ethics in Research Committee of UNIFESP (CEP 1564/08), as well as for authorization by CACM Outpatient Coordination.

\section{RESULTS}

It was found that the majority of the children (57.5\%) were of the female sex, in the age range between 0 and 12 months (53.7\%). With regard to the maternal age ranges, it was noted that $37.5 \%$ were between 20 and 29 years. In regard to the level of education, the majority of them $(37.5 \%)$ had not completed elementary school. It was verified that they had all completed prenatal care.In the cross mapping, 450 nursing diagnoses were encountered recorded in the 80 nursing records analyzed in the period of six months, which corresponded to $20 \%$ of the total of the consults conducted monthly in the outpatient clinic. These 450 nursing diagnoses presented similarities between them and were grouped into 56 nursing 
diagnoses; 33 (58.9\%) corresponded to the Nomenclature of Curitiba and $23(41.1 \%)$ corresponded to the focus terms of practice and judgment of ICNP ${ }^{\circledR}$ 1.0. For example: normal growth of the child (ICNP $\left.{ }^{\circledR} 1.0\right)$ corresponded with the following nursing diagnoses registered in the charts: eutrophic child, adequate growth, child with upward growth curve. Of the 56 equivalent diagnoses encountered, $43(76.8 \%)$ were considered diagnoses of deviation from normalcy and 13 (23.2\%) were considered diagnoses of normalcy.

Table 1 - Distribution of the nursing diagnoses of normalcy encountered in the infant health nursing consults in the Cruz de Malta Care Center - São Paulo, 2009

\begin{tabular}{lcc}
\hline Nursing Diagnoses of Normalcy & N & \% \\
\hline $\begin{array}{l}\text { Growth and development } \\
\text { Adequate child growth * }\end{array}$ & 56 & 26,3 \\
$\begin{array}{l}\text { Adequate child development * } \\
\text { Immunological regulation }\end{array}$ & 54 & 25,4 \\
$\begin{array}{l}\text { Adequate vaccination status* } \\
\text { Nutrition }\end{array}$ & 44 & 20,6 \\
$\begin{array}{l}\text { Adequate dietary intake of the infant } \\
*\end{array}$ & 21 & \\
$\begin{array}{l}\text { Adequate breastfeeding * } \\
\text { Adequate breastfeeding * }\end{array}$ & 15 & 7,9 \\
$\begin{array}{l}\text { Adequate breastfeeding * } \\
\text { Therapeutic }\end{array}$ & 7 & 3,2 \\
$\begin{array}{l}\text { Adequate control of the therapeutic } \\
\text { regimen * } \\
\text { Body care }\end{array}$ & 6 & 2,8 \\
$\begin{array}{l}\text { Adequate self-care* } \\
\text { Gregariousness }\end{array}$ & & \\
$\begin{array}{l}\text { Family bond present* } \\
\text { Bond between mother and child } \\
\text { preserved * } \\
\text { Elimination }\end{array}$ & 4 & 1,9 \\
$\begin{array}{l}\text { Adequate bowel elimination* } \\
\text { Adequate sleep* } \\
\text { Cutaneous mucosal integrity }\end{array}$ & 1 & 0,5 \\
Normal dentition** & 2 & 0,5 \\
\hline Total & 1 & 0,5 \\
\hline & & 0,5 \\
\hline
\end{tabular}

* Nursing diagnoses contained in the Nomenclature of Curitiba.

**Nursing diagnoses contained in ICNP ${ }^{\circledR} 1.0$.

In Table 1 it is verified that the diagnosis of normalcy most recorded in the nursing consultations was adequate child growth, which appeared 56 times in different consultations, equivalent to $26.3 \%$ of the total number of positive diagnoses, followed by the diagnosis of dequate child development (25.4\%), which appeared 54 times.

Among the diagnoses of deviation from normalcy, it can be seen in Table 2 that the most frequent were the diagnoses of cutaneous - mucosal integrity, responsible for $29.0 \%$ of the negative diagnoses encountered in the analyzed consultations, appearing 69 times. In this group of diagnoses, the most recorded was the impaired cutaneous-mucosal integrity, recorded 22 times (9.3\%). The nursing diagnosis most encountered, relative to skin problems, which specified the type of injury was the diagnosis of diaper rash, which appeared 13 times, corresponding to $5.5 \%$ of the diagnoses of abnormalities. The second most frequent diagnosis of abnormality was inadequate dietary intake of the infant (10.1\%), appearing 24 times, followed by the diagnosis of early weaning of the infant (8.4\%), which appeared 20 times (Table 2).

Table 2 - Distribution of the diagnoses of deviations of normalcy encountered in the infant health nursing consults in the Cruz de Malta Care Center - São Paulo, 2009

\begin{tabular}{|c|c|c|}
\hline $\begin{array}{l}\text { Nursing diagnoses of deviations of normalcy } \\
\text { Nutrition }\end{array}$ & $\mathbf{N}$ & $\%$ \\
\hline Inadequate dietary intake of the infant * & 24 & 0,8 \\
\hline Early weaning of the infant $*$ & 20 & 0,8 \\
\hline Weight loss* & 3 & 1,3 \\
\hline Inadequate breastfeeding* & 2 & 0,8 \\
\hline Risk for malnutrition $* *$ & 2 & 0,8 \\
\hline \multicolumn{3}{|l|}{ Cutaneous-mucosal integrity } \\
\hline Impaired integrity of the skin in the infant* & 22 & 9,3 \\
\hline Diaper rash ${ }^{* *}$ & 13 & 5,5 \\
\hline Fissure** & 7 & 2,9 \\
\hline Perineal candidiasis $* *$ & 6 & 2,5 \\
\hline Seborrheic dermatitis** & 6 & 2,5 \\
\hline Dry skin** & 5 & 2,1 \\
\hline Heat rash** & 4 & 1,7 \\
\hline Parasitic infestation** & 3 & 1,3 \\
\hline Mammary engorgement* & 2 & 0,8 \\
\hline Foul odor of the ear** & 1 & 0,4 \\
\hline \multicolumn{3}{|l|}{ Growth and development } \\
\hline Inadequate child growth* & 20 & 8,4 \\
\hline Inadequate child development* & 4 & 1,7 \\
\hline Compromised motor reflex $* *$ & 1 & 0,4 \\
\hline Overweight* & 1 & 0,4 \\
\hline \multicolumn{3}{|l|}{ Therapeutic } \\
\hline Risk for Vitamin D deficiency** & 16 & 6,7 \\
\hline Inadequate control of the therapeutic regimen* & 10 & 4,2 \\
\hline Risk for compromised tissue perfusion $* *$ & 2 & 0,8 \\
\hline Impaired tissue perfusion** & 1 & 0,4 \\
\hline \multicolumn{3}{|l|}{ Oxygenation } \\
\hline Dyspnea** & 12 & 5,1 \\
\hline Compromised permeability of the airways $*$ & 5 & 2,1 \\
\hline Risk of dyspnea in the child* & 3 & 1,3 \\
\hline Risk of aspiration** & 1 & 0,4 \\
\hline \multicolumn{3}{|l|}{ Sleep and rest } \\
\hline Inadequate sleep* & 8 & 3,4 \\
\hline \multicolumn{3}{|l|}{ Immunological regulation } \\
\hline Delayed vaccine status* & 4 & 1,7 \\
\hline Compromised immunological status* & 1 & 0,4 \\
\hline \multicolumn{3}{|l|}{ Body care } \\
\hline Inadequate self-care* & 4 & 1,7 \\
\hline
\end{tabular}




\begin{tabular}{lcc}
...Continuation & & \\
\hline $\begin{array}{l}\text { Nursing diagnoses of deviations of normalcy } \\
\text { Nutrition }\end{array}$ & N & \% \\
\hline Altered genital hygiene* & 3 & 1,3 \\
Altered body hygiene* & 1 & 0,4 \\
Elimination & & \\
Intestinal constipation** & 3 & 1,3 \\
Gastrointestinal colic** & 2 & 0,8 \\
Regurgitation** & 2 & 0,8 \\
Presence of intestinal parasite** & 1 & 0,4 \\
Enuresis** & 1 & 0,4 \\
Gregariousness & & \\
Conflictual family relationship* & & \\
Compromised bond with father** & 3 & 1,3 \\
Compromised mother-child bond* & 2 & 0,8 \\
Risk for pregnancy $* *$ & 2 & 0,8 \\
Impaired family support* & 2 & 0,8 \\
\hline Total & 1 & 0,4 \\
\hline
\end{tabular}

* Nursing diagnoses contained in the Nomenclature of Curitiba.

${ }^{*}$ Nursing diagnoses contained in ICNP ${ }^{\circledR} 1.0$.

\section{DISCUSSION}

More than half of the nursing diagnoses that appeared in the nursing consultations analyzed had correspondence with the diagnoses contained in the Nomenclature of Nursing Diagnosis and Interventions adopted in the basic network of Curitiba, which was based on the ICNP ${ }^{\circledR}$ Beta 2 version, published in 2002.

The others were mapped to ICNP ${ }^{\circledR}$ Version 1.0, published in 2005, due to the fact they were not included in said nomenclature, which does not contain the totality of infant health nursing diagnoses. Moreover, the ICNP ${ }^{\circledR}$ version 1.0 introduces focus terms of practice and more specific judgments that were not contained in the Beta 2 version, which was used to build the Nomenclature of Curitiba.

The analysis of these results was performed considering the 43 diagnoses of deviation from normalcy and the 13 diagnoses of normalcy. Interestingly, both in situations of normalcy and in those of abnormality, 77 (96.0\%) of the 80 infant health nursing consultations analyzed in this study were concerned to assess and record the condition of infant growth, in accordance with the standard of reference recommended by the Ministry of Health ( $\mathrm{MOH})$.

The diagnosis of development was cited in 60 consultations, corresponding to $75 \%$ of cases. This finding is important, because it shows that the nurses in the clinic studied complied with the recommendation of the $\mathrm{MOH}$ to meet one of the established basic actions, which is to monitor the growth and development of children under five years of age seen in all basic network health services.
It is known that infant growth is considered one of the best indicators of health of the child, due to its close dependency on social factors related to: type of food in quantity and quality; occurrences and types of diseases; health care and vaccination; affectionateness of the family with the child; living conditions, especially housing and basic sanitation; and access to health services ${ }^{(15)}$. Therefore, adequate monitoring of child growth is recognized and recommended as an important health action.

It was also possible to perceive the preoccupation of the nurses to assess and record the vaccination status of the children being seen. The diagnosis of adequate vaccination status and delayed vaccination status were cited in 48 consultations, corresponding to $60.0 \%$ of the visits. The result shows the need for nurses to identify, orient and register the vaccination status in all visits performed, in accordance with the recommendation of the Immunization Programs that encourage protection against immunopreventable diseases, aimed at increasing vaccination coverage.

It was further found that in $36(45.0 \%)$ visits, the children were aged equal to or less than six months, a period in which there is a need for assessment of breastfeeding. The diagnosis of early weaning was found in 20 consultations, highlighting the need for encouragement and guidance about breastfeeding in prenatal and infant health consultations, as well as promoting relactation.

Dietary intake of infants appeared in 45 of the analyzed consultations; in 24 of them the infant's food intake was inadequate and in 21 the feeding was satisfactory. Diagnoses related to food ingestion and exclusive breastfeeding were cited in 62 (77.5\%) consultations, as it is important for the promotion of child health that they are recorded in all visits in order to define possible effective nursing interventions.

It is worth mentioning the results regarding the evaluation of cutaneous and mucosal integrity, which, although not considered a basic action by the $\mathrm{MOH}$, was found very frequently in the nursing consultations analyzed. Diagnoses related to this problem appeared 70 times in the 80 well child nursing consultations analyzed, and in 69 , deviations from normalcy were identified. Studies have demonstrated the high prevalence of these clinical findings in nursing consultations aimed at monitoring growth and development, which confirms the relevance of identifying cutaneousmucosal problems in infants, for the determination of early and adequate nursing intervention ${ }^{(16)}$.

The nursing diagnoses most often found related to aspects of nutrition, growth and development, and vaccination status, which are addressed in the child health programs developed by the Municipal Health Secretary of São Paulo.

One study conducted in Curitiba with respect to the nursing practices executed by professional nurses in primary care showed that nursing consults with children conducted in the period of August to December of 2005 generated 28 nursing diagnoses, with an emphasis on 
diagnoses of normalcy, which appeared in a higher number than those of deviations in normalcy ${ }^{(17)}$.

It is worth remembering that nursing diagnoses are indicators of necessary nursing care, and they favor the development of the body of nursing knowledge, to the extent that they generate interventions and the need for research about them ${ }^{(17)}$. Due to the importance of recognizing nursing care and its respective interventions, we must regard as a routine the description of the nursing diagnoses during nursing consultations ${ }^{(18)}$.

Classification systems enable visualization of nursing practices, and reflect on daily care, both for the individual as well as for the community ${ }^{(19)}$.

\section{CONCLUSION}

In this study it was possible to perceive that nursing consultations for the child brought a great amount of

\section{REFERENCES}

1. Saparolli ECL, Adami NP. Avaliação da qualidade da consulta de enfermagem à criança no Programa de Saúde da Família. Acta Paul Enferm. 2007;2(1):55-61.

2. Costa CR, Fracolli LA. O processo de enfermagem em atenção primária à saúde. In: Santos AS, Miranda SMR, organizadores. A enfermagem na atenção primária à saúde. Barueri: Manole; 2007. p. 147-65.

3. Cunha SMB, Barros ALBL. Análise da implantação da Sistematização da Assistência de Enfermagem, segundo modelo conceitual de Horta. Rev Bras Enferm. 2005;58(5):568-72.

4. Souza MF, Barros ALBL, Michel JLM. Bases teórico-metodológicas para a coleta de dados de enfermagem. In: Barros ALBL, organizadora. Anamnese e exame físico: avaliação diagnóstica de enfermagem no adulto. Porto Alegre: Artmed; 2002. p.19-35.

5. Cruz DALM. A inserção do diagnóstico de enfermagem no processo assistencial. In: Cianciarullo, organizadora. Sistema de Assistência de Enfermagem: evolução e tendências. São Paulo: Ícone; 2001. p. 63-84.

6. Cruz DALM. Diagnósticos de enfermagem. In: Garcia TR, Egry EY, organizadoras. Integralidade da atenção no SUS e Sistematização da Assistência de Enfermagem. Porto Alegre: Artmed; 2010. p.111-7.

7. Nobrega MML, Garcia TR. Perspectivas de incorporação da Classificação Internacional para Prática de Enfermagem (ClPE) no Brasil. Rev Bras Enferm. 2005;58(2):227-30. content for well child care, both situations of normalcy and abnormality, with emphasis on the diagnosis of deviation from normalcy.

The use of the cross-mapping method allowed for the comparison of the information from existing records of children seen in nursing consultation, with nursing diagnoses standardized by the ICNP ${ }^{\circledR}$, which may contribute to the implementation of the classification system in the clinic where the children were assisted.

The standardization of language allows the documentation of nursing information, contributing to patient care and facilitating communication among nurses and other health professionals. The use of ICNP ${ }^{\circledR}$ as a unifying framework for all systems of classification of elements of professional practice can help to systematize nursing care in the Unified Health System (SUS), in order to profile the quality of professional care, leading to significant benefits for the profession.

8. Lucena AF, Barros ALBL. Mapeamento cruzado: uma alternativa para a análise de dados em enfermagem. Acta Paul Enferm. 2005;18(1):82-8.

9. Garcia TR, Cubas MR, Almeida MA. Resultados de enfermagem. In: Garcia TR, Egry EY organizadoras. Integralidade da atenção no SUS e Sistematização da Assistência de Enfermagem. Porto Alegre:Artmed; 2010. p. 125-34.

10. Silva RR, Malucelli A, Cubas MR. Classificações de enfermagem: mapeamento cruzado entre termos do foco da prática. Rev Bras Enferm. 2008;61(6):835-40.

11. Garcia TR, Nobrega MML, Sousa MCM. Validação das definições de termos identificados no projeto CIPESC para o eixo foco da prática de enfermagem da CIPE. Rev Bras Enferm. 2002;55(6):52-63.

12. Garcia TR, Nobrega MML. Inventário vocabular resultante do Projeto CIPESC CIE- ABEn. In: Garcia TR, Egry EY, organizadoras. Integralidade da atenção no SUS e Sistematização da Assistência de Enfermagem. Porto Alegre: Artmed; 2010. p. 192-317

13. Albuquerque LM, Cubas MR, organizadores. Cipescando em Curitiba: construção e implementação da nomenclatura de diagnósticos e intervenções de enfermagem na rede básica de saúde. Brasília: ABEn; 2005.

14. Comitê Internacional de Enfermeiros. CIPE Versão 1: Classificação Internacional para a Prática de Enfermagem. São Paulo: Algol; 2007 
15. Brasil. Ministério da Saúde; Secretaria de Políticas de Saúde, Área temática de Saúde da Criança. Fundamentos teóricocientíficos e orientações práticas para o acompanhamento do crescimento e desenvolvimento. Brasília; 2000.

16. Saparolli ECL, Andrade PR. Principais dermatoses na infância. In: Fujimori E, Ohara CVS, organizadoras. Enfermagem e a saúde da criança na atenção básica. Barueri: Manole; 2010. p. 417-40.

17. Apostólico MR, Cubas MR, Altino DM, Pereira KCM, Egry EY. Contribuições da CIPESC na execução das políticas de atenção à saúde da criança no Município de Curitiba. Texto Contexto Enferm. 2007;16(3):417-40.
18. Nóbrega MML, Garcia TR, Chianca TCM, Almeida MA. Estrutura da CIPE, da NANDA, da NIC e da NOC. In: Garcia TR, Egry EY organizadoras. Integralidade da atenção no SUS e Sistematização da Assistência de Enfermagem. Porto Alegre: Artmed; 2010. p. 157-71.

19. Cubas MR, Egry EY. Classificação Internacional das Práticas de Enfermagem - CIPESC. Rev Esc Enferm USP. 2008;42(1):181-6. 